\title{
A Paradigm Interpreting the City and the Analytic Network Process for the Management of Urban Transformations
}

\author{
Grazia Napoli $^{1(\bowtie)}(\mathbb{D})$, Salvatore Giuffrida ${ }^{2}(\mathbb{D}$, \\ and Maria Rosa Trovato ${ }^{2}$ (D) \\ ${ }^{1}$ University of Palermo, 90128 Palermo, Italy \\ grazia.napoli@unipa.it \\ ${ }^{2}$ University of Catania, 95131 Catania, Italy
}

\begin{abstract}
When urban and environmental transformations occur in areas where the equilibrium between nature and culture is complex and fragile, public administrations could decide to induce private investments using several tools, such as financial contributions to those projects of refurbishment that better respect the purpose of improving the environmental quality and of preserving the local architecture. Multicriteria models may support public decision process regarding this issue, but it is essential to adopt a scientific paradigm that provides a major theoretical reference. This study proposes the development of a network model based on the scientific paradigm by Rizzo and the Analytic Network Process. The first one has been chosen because of its interpretation of the city as autopoietic organization, dissipative structure and political-administrative system, the second one because of its holistic representation of the decision problem in which the interactions between all the elements are made explicit. The network model has been applied to a case study that consists in ranking some alternative refurbishments of buildings in Favignana (Egadi islands, Italy) in order to grant public financial contributions.
\end{abstract}

Keywords: Analytic Network Process · Multicriteria analysis

Urban transformation · Decision aid

\section{Introduction}

The role of multicriteria decision models may be considered an action of supporting the evolutionary, adaptive, and cognitive process of reworking of the new data and knowledge acquired by the Decision Maker (DM), who operates in complex and adversarial social-territorial contexts $[1,2]$. In fact, multicriteria analysis has the following several characteristics: it is able to represent the complex levels of an evaluation problem; it can involve many stakeholders in the evaluation process by using participation techniques that make clear all steps of the decision process and make explicit any social convergence or conflict; it clearly communicates the social value system and the judgments on which the decision process is based. This action, however, should be 
founded on a scientific paradigm that provides an interpretative key to manage the extreme variety of multicriteria models. These models belong to different "families" of methods, each of them follows a proper logical-mathematical approach to elaborate data and to deal with specific decision problems (such as solving, ranking, sorting and designing) [3].

This study proposes to assume the interpretative paradigm by Rizzo [1, 4], which considers the city as autopoietic organization, dissipative structure and a politicaladministrative system, as the reference from which an Analytic Network Process ANP- model is developed. The network is applied to a case study consisting in ranking some alternative refurbishments of buildings in Favignana (Egadi islands, Italy) in order to grant public subsidies to those projects that better preserve the local architecture and improve the environmental quality.

\section{A Paradigm Interpreting the City and the ANP Model}

The scientific paradigm conceived by Rizzo [4] interprets the city as an autopoietic organization, a dissipative structure and a political-administrative system. According to Prigogine's though [5], a dissipative structure is a structure that evolves itself creating order from disorder when it is distant from the equilibrium point and is subjected by perturbations. This theory, which was firstly developed with regard to chemical structures, is analogous to the description of autopoietic structures as structures that transform themselves though maintaining their own organization [6]. These concepts may be applied to the city because any urban transformations have to respect the principle of sustainability and minimize the consumption of energetic and natural resources, and because the city is able to maintain over time its organization and identity. Moreover a political administrative system provides development and competitiveness to the city when it is efficient and inclusive, e.g. reducing bureaucratic times and promoting social participation in the urban management.

The development of a multicriteria model for the application to a public decision process is more than a mere technical phase because it requests of being strictly referred to a scientific paradigm that provides a consensual linguistic dominion on which the decision are based [7]. This study has developed an Analytic Network Process model to solve decision problems regarding alternatives of urban transformation, according to the aim of taking into account the paradigm by Rizzo in the multicriteria analysis. In fact, nevertheless many different multicriteria models are available in the literature [8-13], the Analytic Network Process has the peculiarity of adopting a holistic approach that is able to best represent the complexity of the decision problem and the interrelations between all the elements of the network [14-18]. The ANP methodology is composed of several steps: the first one is to delineate the DM's objective identifying the alternatives, the clusters of nodes, as well as the feedback or dependence relationships between all of them. Afterward, the DM expresses pairwise comparison measurements according to a ratio scale. The ranking of the alternatives is obtained through the calculation of several supermatrixes [13, 14]. 


\section{The Case Study: Refurbishment Projects of Urban Real Estate in Favignana Island}

The network model has been developed for a case study in Favignana island. The "morphology" of Favignana is the outcome of the long-term relationship between natural environment and human actions; in particular the morphology of the cityscape is generated by the relationships between many elements, such as quarries, road system, private and public external spaces, and buildings [17]. That makes these natural/artificial contexts unique and generates the commitment of public administrations to implement sustainable development policies and measures in order to preserve them.

The decision problem of this case study consists of ranking some alternative refurbishments of real estate properties in the urban center of Favignana, in order to grant public financial contributions to those projects that allow maintaining the local architecture as well as increasing the market value or social use value of the buildings. The development of a multicriteria model depends on the need to take a choice on the basis not only of financial parameters such as cost of refurbishment, cost of energetic retrofit, or market prices [19-21], but also of qualitative parameters such as the environmental quality and the compliance with the "rules" of the local traditional architecture [22-24].

The alternatives are, as an example, the projects of refurbishment of five buildings, namely A, B, C, D, and E, which are located in an urban bock (Fig. 1). The projects have different characteristics with reference to: size and typology of the project maintenance, alteration, partial demolition and rebuilding-, costs, technological installations, relationships between internal and external spaces or between building and public spaces, etc.

\subsection{The Development of the ANP Model}

The DM is formed by various experts, such as a public administration official, a local professional (architect), and a real estate developer. They interacted in a focus group for specifying the three interpretative keys of the city by Rizzo, formerly described, into a network model. During meetings, the model was discussed and reviewed until to reach a consensus on a network that consists of 6 clusters and 22 nodes. The 6 clusters are: "Urban real estate autopoiesis", "Consensual linguistic dominion", "Operative financial plasticity", "Decisional efficiency and social participation", "Non-entropy and energetic efficiency", and "Alternatives". The clusters are briefly described in Table 1, whereas Fig. 2 shows the structure of the network: the clusters, the nodes, and the relationships between the clusters.

Following the ANP procedure, for each cluster the DM expresses judgments on pairwise comparisons of elements -according to Saaty's fundamental scale [13] - in accordance with another element of the network to which they have a relationship. The pairwise comparisons follow the relationships -dependence, feedback, and loop- that were designed in the network by the DM. The judgments allow achieving the paired comparison matrixes and afterwards three supermatrixes are calculated: the unweighed 


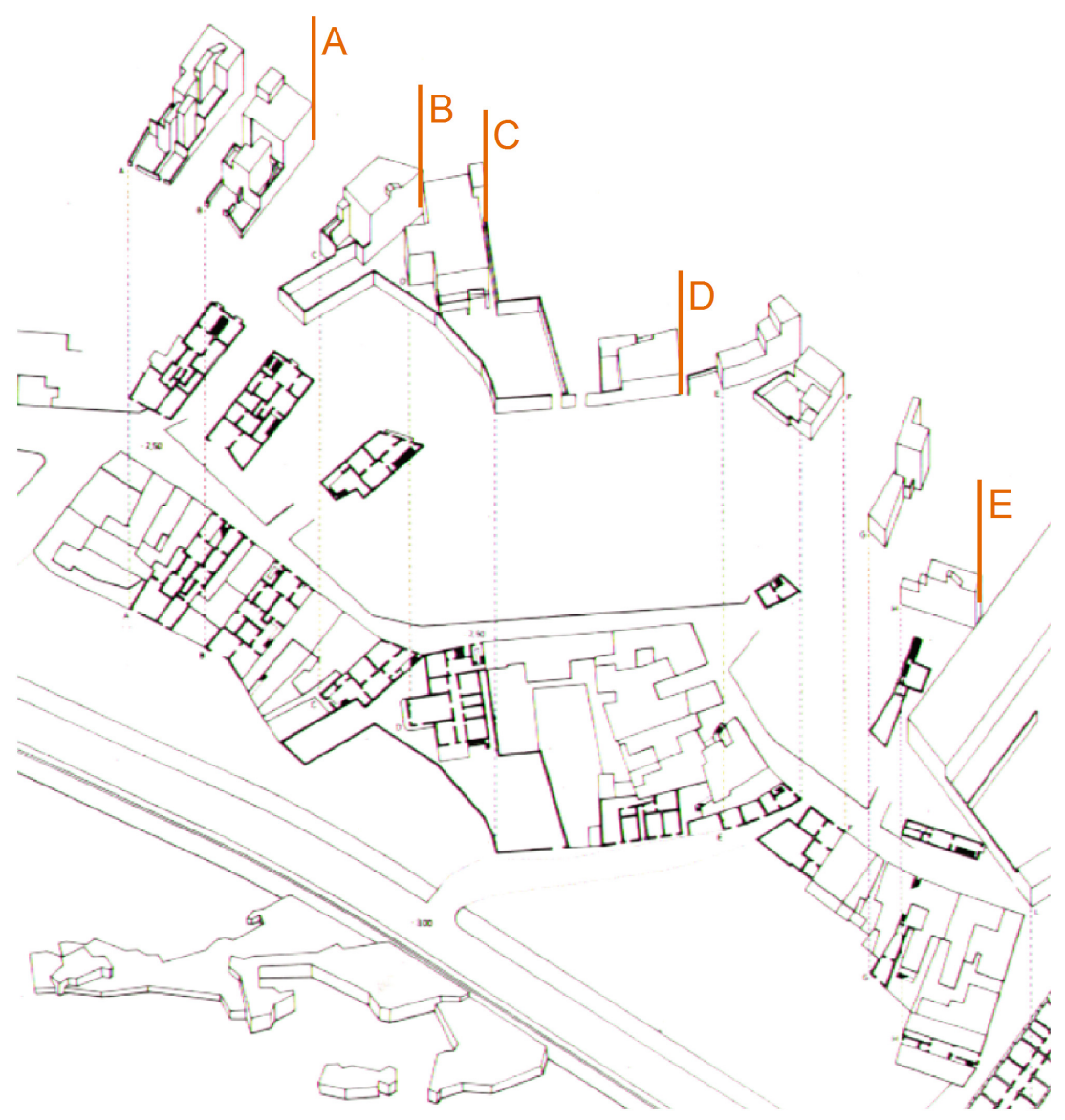

Fig. 1. The alternatives in an urban block in Favignana

one consists of $\mathrm{N} \times \mathrm{N}$ blocks $\mathrm{Wj}$, where $\mathrm{N}$ is the number of the clusters, and $\mathrm{n}$ is the number of nodes of the cluster $\mathrm{N}$-th, the weighed one that is calculated applying to the former matrix the eigenvector obtained from the cluster-level comparison, and finally the limit supermatrix by applying the formula (1).

$$
\lim _{n \rightarrow \infty}(W)^{-1}
$$

\subsection{The Results of the Procedure}

The implementation of the procedure, by using the SuperDecisions 2.8 software [25], gives as results: the priorities between the clusters, the priorities by clusters, and the ranking of the alternatives (Tables 2 and 3). The priorities between the clusters reveal that both the "Consensual linguistic dominion" and "Urban real estate autopoiesis" clusters have the greatest weights because the DM gives more importance to the 
Table 1. Description of the clusters of the model

\begin{tabular}{|c|c|c|}
\hline Criteria & Clusters & Description \\
\hline \multirow[t]{3}{*}{$\begin{array}{l}\text { Autopoietic } \\
\text { organization }\end{array}$} & $\begin{array}{l}\text { Urban real estate } \\
\text { autopoiesis }\end{array}$ & $\begin{array}{l}\text { The urban real estate autopoiesis describes the } \\
\text { ability of a city to maintain its own structure } \\
\text { and the local architecture through } \\
\text { transformation and plus-valorization of the } \\
\text { real estate properties by promoting } \\
\text { investments }\end{array}$ \\
\hline & $\begin{array}{l}\text { Consensual linguistic } \\
\text { dominion }\end{array}$ & $\begin{array}{l}\text { The construction of a linguistic consensual } \\
\text { dominion as a basis of the communication and } \\
\text { of the social consensus is founded on the } \\
\text { increase of the quality of public spaces }\end{array}$ \\
\hline & $\begin{array}{l}\text { Operative financial } \\
\text { plasticity }\end{array}$ & $\begin{array}{l}\text { A city has a financial operational plasticity } \\
\text { when it is able: to employ effectively public } \\
\text { and private capitals, to respect the } \\
\text { programmed terms of realization, and to get } \\
\text { the financial feasibility for the projects of } \\
\text { transformation }\end{array}$ \\
\hline $\begin{array}{l}\text { Political } \\
\text { administrative } \\
\text { system }\end{array}$ & $\begin{array}{l}\text { Decisional efficiency } \\
\text { and social participation }\end{array}$ & $\begin{array}{l}\text { In the city assumed as a } \\
\text { political-administrative system, the increasing } \\
\text { of the decisional efficiency plays an important } \\
\text { role in terms of assuring the involvement of } \\
\text { social groups, of reducing processing time, } \\
\text { and of favoring the mixed public-private } \\
\text { participation to urban transformations }\end{array}$ \\
\hline $\begin{array}{l}\text { Dissipative } \\
\text { structures }\end{array}$ & $\begin{array}{l}\text { Non-entropic and } \\
\text { energetic efficiency }\end{array}$ & $\begin{array}{l}\text { Energetic efficiency and supporting } \\
\text { neg-entropic activities may be achieved } \\
\text { through many actions, such as the refurbishing } \\
\text { of existing buildings to reduce their } \\
\text { deterioration and to improve their energetic } \\
\text { efficiency }\end{array}$ \\
\hline
\end{tabular}

cityscape and the local architecture than to the minimization of financial costs or processing time.

The priority by clusters synthetizes the system of weights implicitly expressed by DM's judgments in order to apply the theoretical concept expressed by the clusters to the case study. For example, the DM judges the "Plus-valorization of the real estate" node as that element that best contributes to implement the "Urban real estate autopoiesis" because the increasing of prices corresponds to a semiotic translation -in monetary terms- of the significance that the social system gives to each category of capital goods and it also measures how much the investors believe in the future real estate market prices [26-28]. By contrast, all the nodes in the "Consensual linguistic dominion" cluster have similar weights as they have the same role in order to represent the characteristics of the local architecture; the low weight of the "Link building/quarry" node only depends on the fact that the quarry is almost nonexistent in the case study. 


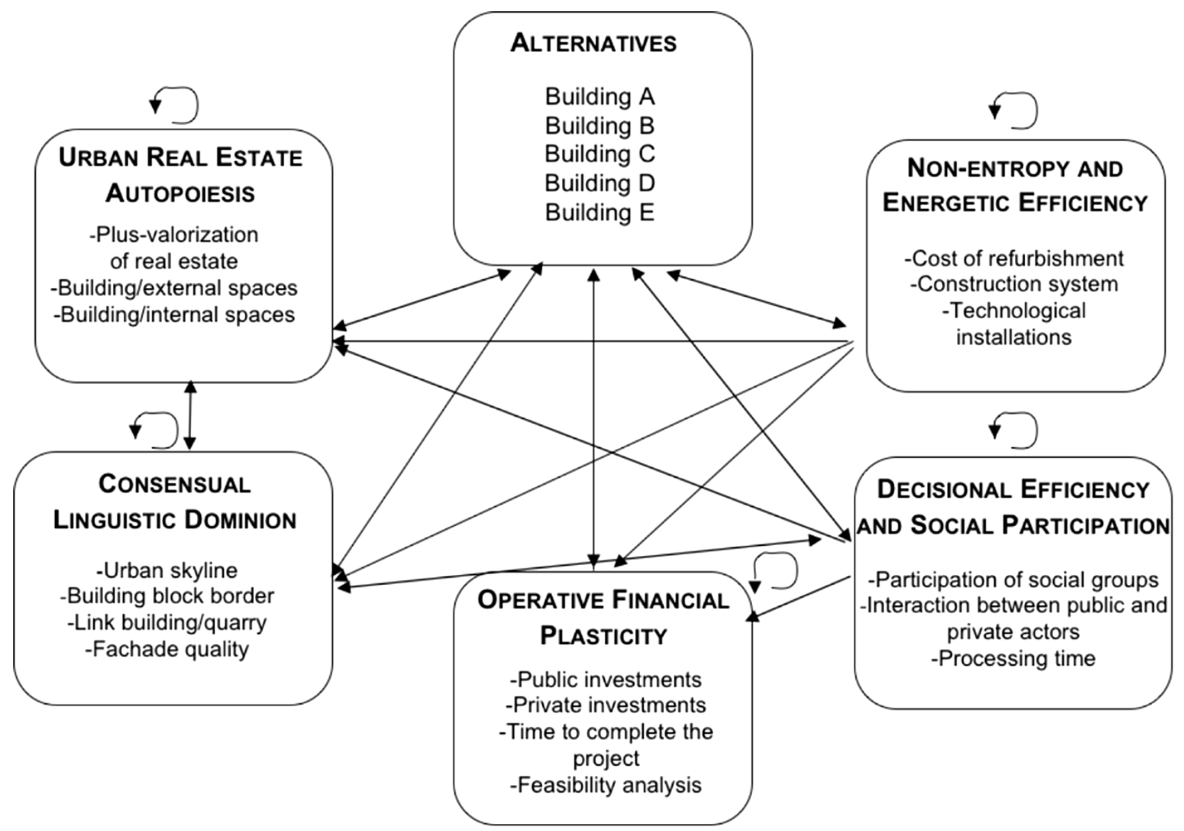

Fig. 2. The network model

Table 2. Priorities between and by clusters

\begin{tabular}{l|l|l|l}
\hline Clusters & Nodes & Normalized & Limiting \\
\hline \multirow{2}{*}{ Urban real estate autopoiesis 0.362} & Plus-valorization real estate & 0.79403 & 0.116899 \\
\cline { 2 - 4 } & Building/external space & 0.09098 & 0.013394 \\
\cline { 2 - 4 } & Building/internal space & 0.11500 & 0.016930 \\
\hline \multirow{4}{*}{$\begin{array}{l}\text { Consensual linguistic dominion } 0.395 \\
0.046\end{array}$} & Urban skyline & 0.34406 & 0.117568 \\
\cline { 2 - 4 } & Building block border & 0.26105 & 0.089202 \\
\cline { 2 - 4 } & Link building/quarry & 0.08505 & 0.029063 \\
\cline { 2 - 4 } & Fachade quality & 0.30985 & 0.105878 \\
\hline \multirow{2}{*}{ Non-entropic and energetic efficiency 0.080} & Participation social groups & 0.84845 & 0.071175 \\
\cline { 2 - 4 } & Interaction private/public & 0.03902 & 0.003273 \\
& actors & & \\
\cline { 2 - 4 } & Processing time & 0.11253 & 0.009440 \\
\hline & Cost of refurbishment & 0.64471 & 0.021608 \\
\cline { 2 - 4 } & Construction system & 0.22276 & 0.007466 \\
\cline { 2 - 4 } Operative financial plasticity 0.117 & Technological installation & 0.13253 & 0.004442 \\
\hline & Public investment & 0.10319 & 0.006734 \\
\cline { 2 - 4 } & Private investment & 0.25003 & 0.016317 \\
\hline & Time to complete project & 0.11941 & 0.007793 \\
\cline { 2 - 4 } & Feasibility analysis & 0.52737 & 0.034417 \\
\hline
\end{tabular}


The final priority vector is coincident to a column of the limit supermatrix and provides the ranking of the alternatives. The buildings $C$ and $D$ are the best alternatives, whereas the others have very low scores, so it could be appropriate to suggest that the DM should set a threshold -minimum score- for obtaining public grants.

Table 3. Rankings of the alternatives

\begin{tabular}{l|l|l|l}
\hline Alternatives & Ranking & Normals & Ideals \\
\hline Building A & 4 & 0.145465 & 0.466064 \\
\hline Building B & 3 & 0.174619 & 0.559472 \\
\hline Building C & 1 & 0.312114 & 1.000 .000 \\
\hline Building D & 2 & 0.253863 & 0.813364 \\
\hline Building E & 5 & 0.113938 & 0.365052 \\
\hline
\end{tabular}

\section{Conclusions}

The development of an ANP model on the basis of the paradigm by Rizzo, which considers the city an autopoietic organization, dissipative structure, and political-administrative system, and its application to a case study in Favignana have been aimed at supporting the public decision making process, especially when urban transformations are damaging the complex and fragile equilibrium between nature and culture, and public authorities are making attempts to preserve the local identity, architecture, and environment.

The model compares five alternatives of refurbishment of buildings and provides the ranking to establish the priority in the granting of public financial contributions in the case of limited public funds. The model could be improved by activating participatory process with a consistent number of stakeholders. The ranking may be a strong starting point to express the complexity of the social values and to support the public decision process for the implementing of a sustainable policy.

\section{References}

1. Rizzo, F.: Valore e valutazioni. La scienza dell'economia o l'economia della scienza. Franco Angeli, Milano (1999)

2. Maturana, H.R., Varela, F.J.: L'albero della conoscenza. Garzanti, Milano (1987)

3. Figueira, J., Greco, S., Ehrgott, M. (eds.): Multiple Criteria Decision Analysis. State of the Art Survey. Springer, New York (2005)

4. Rizzo, F.: Il capitale sociale della città. Valutazione, pianificazione e gestione. Franco Angeli, Milano (2002)

5. Prigogine, I., Stengers, I.: La nuova alleanza. Metamorfosi della scienza. Einaudi, Torino (1981)

6. Maturana, H.R., Varela, F.J.: Autopoiesi e cognizione. La realizzazione del vivente. Marsilio, Venezia (1985) 
7. Luhmann, N.: Sistemi sociali. Fondamenti di una teoria generale. Il Mulino, Bologna (1990)

8. Bana e Costa, C.A., Vansnick, J-C.: Applications of the Macbeth approach in the framework of an additive aggregation model. J. Multi-Criteria Decis. Anal. 6(2), 107-114 (1997)

9. Bouyssou, D., Marchant, T., Pirlot, M., Tsoukiàs, A., Vincke, P.: Evaluation and Decision Models: Stepping Stones for the Analyst. Springer, Berlin (2006)

10. Brans, J., Vincke, P.: A preference ranking organization method: the Promethee method. Manag. Sci. 31, 647-656 (1985)

11. Greco, S., Matarazzo, B., Slowinski, R.: Rough sets theory for multicriteria decision analysis. Eur. J. Oper. Res. 129, 1-47 (2001)

12. Roy, B., Bouyssou, D.: Aide multicritére à la décision: méthodes et case. Economica, Paris (1995)

13. Saaty, T.L.: The Analytic Hierarchy Process. McGraw Hill, New York (1980)

14. Saaty, T.L.: Theory and Applications of the Analytic Network Process. RWS Publications, Pittsburgh (2005)

15. Saaty, T.L., De Paola, P.: Rethinking design and urban planning for the cities of the future. Buildings 7, 76 (2017)

16. Bottero, M., Ferretti, V.: An analytic network process-based approach for location problems: the case of a new waste incinerator plant in the province of Torino (Italy). J. Multi-Criteria Decis. Anal. 17, 63-84 (2011)

17. Napoli, G., Schilleci, F.: An application of analytic network process in the planning process: the case of an urban transformation in Palermo (Italy). In: Murgante, B., et al. (eds.) Computational Science and Its Applications - ICCSA 2014. LNCS, vol. 8581, pp. 300-314. Springer, Cham (2014)

18. Napoli, G.: The value of the useless in the urban landscape of small islands. In: Piccinini, et al. (eds.) Proceedings of the 18th IPSAPA/ISPALEM International Scientific Conference: The Usefulness of the Useless in the Landscape Cultural Mosaic: Liveability, Typicality, Biodiversity, pp. 333-339 (2015)

19. Napoli, G., Gabrielli, L., Barbaro, S.: The efficiency of the incentives for the public buildings energy retrofit. The case of the Italian regions of the "objective convergence". Valori e valutazioni 18, 25-39 (2017)

20. Bencardino, M., Nesticò, A.: Demographic changes and real estate values. A quantitative model for analyzing the urban-rural linkages. Sustainability 9(4), 536 (2017)

21. Della Spina, L., Scrivo, R., Ventura, C., Viglianisi, A.: Urban renewal: negotiation procedures and evaluation models. In: Gervasi, O., et al. (eds.) Computational Science and Its Applications - ICCSA 2015. LNCS, vol. 9157, pp. 88-103. Springer, Cham (2015)

22. Nesticò, A., Sica, F.: The sustainability of urban renewal projects: a model for economic multi-criteria analysis. J. Property Investment Fin. 35(4), 397-409 (2017)

23. Della Spina, L.: Integrated evaluation and multi-methodological approaches for the enhancement of the cultural landscape. In: Gervasi, O., et al. (eds.) Computational Science and Its Applications - ICCSA 2017. LNCS, vol. 10404, pp. 478-493. Springer, Cham (2017)

24. Calabrò, F.: Local communities and management of cultural heritage of the inner areas. An application of break-even analysis. In: Gervasi, O., et al. (eds.) Computational Science and Its Applications - ICCSA 2017. LNCS, vol. 10406, pp. 516-531. Springer, Cham (2017)

25. Superdecisions. https://www.superdecisions.com. Accessed 03 Dec 2017

26. Giuffrida, S., Ventura, V., Trovato, M.R., Napoli, G.: Axiology of the historical city and the cap rate. The case of the old town of Ragusa Superiore. Valori e Valutazioni 18, 41-55 (2017) 
27. Napoli, G., Valenti, A., Giuffrida, S.: The urban landscape and the real estate market. Structure and fragment of the axiological tessitura in a wide urban area of Palermo. In: Piccinini, L.C., et al. (eds.) Proceedings of the 19th IPSAPA/ISPALEM International Scientific Conference, Napoli, 2nd-3rd July 2015, pp. 67-78 (2016)

28. Nesticò, A., Galante, M.: An estimate model for the equalisation of real estate tax: a case study. Int. J. Bus. Intell. Data Min. 10(1), 19-32 (2015) 